\title{
The Relationship between Job Rotation and Employee Performance in Level-Four Hospitals within the South- Rift region in Kenya
}

\author{
Sharon Cherotich ${ }^{1}$, Dr. Williter Rop ${ }^{2}$, Dr. Alfred Bett ${ }^{3}$ \\ ${ }^{1}$ (MBA, School of Business and Economics, University of Kabianga, Kenya) \\ ${ }^{2}$ (Lecturer, School of Business and Economics, University of Kabianga - P.O Box 2030-20200 Kericho, Kenya) \\ ${ }^{3}$ (Lecturer, School of Business and Economics, University of Kabianga - P.O Box 2030-20200 Kericho, Kenya) \\ DOI: 10.29322/IJSRP.11.09.2021.p11718 \\ http://dx.doi.org/10.29322/IJSRP.11.09.2021.p11718
}

\begin{abstract}
The health sector in Kenya is one of the key segments that provide the most essential services to the public. Unmatched skills set to job requirement has been found to have a significant impact on performance of employees and the sector in general. Effectiveness of employee training and development programs such as job rotation can bridge the gap between job requirements and employees' ability to perform. However, it is not yet clear to what extent job rotation techniques can influence employee performance. The study therefore sought to assess the relationship between job rotation and employee performance in Level Four Hospitals operating within the South-Rift Region in Kenya. It was anchored on human capital theory, knowledge-based theory of the firm and social learning theory. Correlational and survey research designs were employed with a target population of 663 medical personnel drawn from 13 Level Four Hospitals. A sample size of 249 was determined while stratified simple random sampling method used to pick the respondents. Data was collected by use of structured a questionnaire whose reliability was tested through a pilot study where an average Cronbach alpha coefficient of 0.8102 was obtained. Content, construct and face validity were ensured by carrying out a detailed literature review and consultation with subject experts. Descriptive statistics comprising mean and standard deviation were used to categorize data while the study hypothesis was tested using correlation coefficient. The findings were presented in form of tables. The study established that job rotation had a moderate relationship $\left(\mathrm{R}=0.506, \beta_{1}=0.406\right.$, $\mathrm{R}^{2}=0.256, \mathrm{p}<0.05$ ) with employee performance indicating that Level Four Hospital in South-Rift region should invest in job rotation strategies. The study recommended that Level Four Hospitals in the South-Rift rotate personnel within the job function as it contributes more to their development. The findings may be useful to hospital management, human resource departments, scholars and researchers in in the field of human resources management.
\end{abstract}

Index Terms- Employee; Training; Job Rotation; Health Sector and Performance

\section{INTRODUCTION}

$\mathrm{T}$ he $21^{\text {st }}$ century has seen a dramatic surge on the need to attract and retain talent by organizations due to the effects of globalization, technological innovation, increased competition and the need to have a competitive advantage, (Esteban-Lloret, Aragón-Sánchez \& Carrasco-Hernández, 2018). Employee training has been defined by Morley, Slavic, Poór and Berber, (2016) as a logical development of behaviors, knowledge and skills required by labor force for them to perform a given job or any task assigned to them adequately.

According to Elnaga and Imran (2013), training is any program that equips employees with adequate information, emerging professional skills, or development of professional opportunities. Employees should be given a learning atmosphere that is continuous to enable them have a track of the vision and mission of the organization. Efficiency and effectiveness in operations is the crucial goal of any organization when it comes to its business operation and it is this effort that results in the accomplishment of organizational goals through better leadership and ability to capture unique talents.

The present education system does not equip learners with specific knowledge meant for specific job position in organizations. Therefore, labor force contains few employees with the knowledge, right skills and competencies required by job positions available in the market. This has forced organizations to organize for extensive external and internal training programs which are required by employees as well as to contribute to positive organizational performance, (Njoroge \& Kwasira, 2015).

Mutua (2017) in his assessment of the influence of human resource management practices on employee performance in the health sector in Machakos revealed that training can be conducted through different techniques, away from job training and while on job training. When it comes to job training techniques, it involves equipping employees practically in a working environment. Among the best techniques applied during training include job rotation, orientation, mentoring, coaching, and demonstration. Akbari and Maniei (2017) defines job rotation as a planned onthe-job training geared towards developing and preparing employees for future job engagements by transferring an employee from one department to another to escalate his understanding of the job processes and enhance employees' abilities.

Kuzey (2012) encourages job rotation in organizations claiming that it promotes physical and psychological health of the labor force by developing attitudes positive to the employees, 
escalating variability of work via boredom, reduction, exhibiting intrinsic- motivation enhancing their health towards individual organizational position. Tarus (2014) also approves that the strategy of job rotation if properly implemented in accordance to the goals of the business and strategies of the human resource in an organization could help to stimulate the human mind from end to end of the different challenges.

\subsection{Problem statement}

Universal health care is among the governments' big four agenda and a key pillar for Vision 2030. The health sector has been given priority to ensure that it is efficient in the delivery of services by preparing a policy document in 2012 detailing the guidelines on how to achieve accessible and quality health care for the citizens. This was aligned to the constitution requirements and global health commitments in form of sustainable development goals. Since the adoption of the policy document, there has been very little change in the health sector in terms of service delivery with WHO indicating that performance in the health sector was below $50 \%$. This is largely attributed to shrinking workforce coupled with poor job satisfaction and low employee motivation among others which directly affect service delivery. Some of these issues have been linked with lack of proper training and development techniques that are aimed at imparting the medical personnel with relevant skills to enable them perform their duties well. Several studies have sought to examine the relationship between training techniques and employees' performance, however the findings have not been consistent. The studies have also not exhaustively evaluated all the training techniques and therefore this motivated the researcher to examine the relationship between job rotation and performance of level four hospitals in the south rift region.

The objective of the study was to establish the relationship between job rotation and employee performance in level four hospitals within the South-Rift region in Kenya.

Study hypothesis: There is no significant relationship between job rotation and employee performance in level four hospitals within the South-Rift region in Kenya.

\section{LITERATURE REVIEW}

\subsection{Theoretical Framework}

The study was supported by human capital theory; Knowledge based theory of the firm and social learning theory.

Human capital theory was developed by Becker (1993), the theory emphasizes that training and development is necessary and a worthwhile investment. It addresses how training influences employee efficiency and productivity through constantly developing and improving their cognitive abilities that can make them more work better (Schab, 2018). Since 1950s different researchers have examined this theory and its application in organizations specifically in assessing the value of human capital in the hospital set up and has realized that there is no single model that can be used by organizations in empowering employees. The history of human capital evaluation and measurements help managers in coming up with a paradigm that can indicate the real value of human capital. There is a new perspective on human capital that argues that perfect motivation of the labor force gives a lead towards the theory of self-determination, (Nemeth, 2017).
Those persons who are motivated perfectly are always eager to acquire and learn better skills and also to employ special knowledge and integrate these outcomes into their working habits to enhance company's effectiveness. Basing on this particular theory, it is evident to argue that individuals having intrinsic motivation are valuable for a firm compared to demotivated workers or employees having extrinsic motivation since individuals possessing intrinsic motivation have a desire to accomplish their tasks and thus improving organizational performance (Hage, 2017). Thus, the importance of this theory to the research involves the recognition of employees as important assets to the organization who should be given the right set of skills through various techniques for them to perform efficiently and effectively for optimum organizational output. Therefore, the dependent variable of the study (employee performance) was supported by this theory.

Similarly, Knowledge based theory of the firm as advanced by Winters (1987) explored on explicit knowledge claiming that it replicates fasters, less costly and most importantly easies in comparison to tacit knowledge. He also added that the transfers of this knowledge can only be successful achieved through an interaction involving face to face relations such as apprentice and job rotation. This theory explores the firm's existence arguing that it is because of its unique abilities such as effective management of knowledge at its tacit form and in an effective, efficient and cheapest manner than other governance methodologies.

Inadequate expertise has the disadvantage of making the distribution of knowledge among people difficult. Knowledge based theory emphasize that knowledge is potentially a substantial resource. Its advocates the claim that since resources that are knowledge based are hard to emulate and intricate socially, diverse knowledge bases and potential abilities of different organizations are the main elements of continual superior corporate governance and competitive advantage (Nonaka, and Toyama 2015). The current study makes a case that knowledge can be achieved by rotating employees and this will expose them to different environments which is important in help them gain useful skill. Social learning theory on its part encourages development of good learning environment for employees to build their skills and knowledge. This theory was developed by Bandura (1977) and it emphasizes that individuals learn through imitation, observation and modeling from different people who they perceive to be knowledgeable or that have ability to influence others. The theory is based on the assumption that learning can take place through observing the actions, emotional reactions and attitudes of other people. It also suggests that persons study by making observation about others (Braton, 2007). Observation enables persons to gain knowledge from the behavior of others where they acquire new ideas about what could happen if they act differently or in similarity to them. (Adenyo, 2016).

The theory also stress the need to identify self- efficacy of persons especially when it comes to the training process throughout the assessment stage. Any trainee who has selfefficacy that is high is required to add more effort towards learning during training. On the other hand, in distinction persons in training who have low effectiveness are known to have discomforts related to mastering the general content of the program. They are therefore expected to substantially give in more physically and psychologically from the training program. 
These individuals believe that they cannot learn, notwithstanding their level of effort (Mineka \& Zinbarg, 2006).

Social learning theory gives substantial information which is linked directly to techniques employed by organizations when it comes to training. It promotes training operations to employ the application of methods that enhances the incorporation of skills, knowledge when it comes to the training exercise on a daily basis (Newman, Baum \& Wienman, 1995). In the hospital set up, the strategies used in training including job rotation promotes the ability of employees to get skills relevant in the job. It is essential for the firm to promote job rotation, coaching and teamwork among the labor force so as to promote exchange of information in the job environment and allow labor force to obtain essential skills.

\subsection{Job Rotation and Employee Performance}

Job rotation has been well-defined as the process of switching a person from occupation to another in the same organization with an aim of aggregating an employee's potential capability and organization's value (Halawi \& Haydar, 2018). Job rotation can also be called cross-training, which means a departmental or unit employee can be able to learn diverse skills for a job during a specific period; it is also regarded as a practical approach to enrich and expand job assignments.

A study done by Akbari and Maniei (2017) on the impact of job rotations on performance of employee of Dana insurance company in Tehran reveals that job rotation in the organization can be used for knowledge development. The study was conducted by use of descriptive research design and a sample size of senior managers from the insurance company where a questionnaire with eight questions was administered to the respondents. Data collected was analyzed through regression and correlation models by SPSS. From the findings it was evident that when job rotation was adopted, employees were able to obtain new skills and experiences which increased their performance. This study adopted a descriptive research design while the current study adopted a correlational research design.

Azzopardi, (2019) study on internal job rotation within Maltese audit firms established pointed out that job rotation increases employees' job satisfaction and motivation. In carrying out this study, mixed research techniques were adopted where both the questionnaires and document analysis forms were used to collect primary data secondary data respectively from four large audit firms in Maltese. Regression and correlation models were used to present inferential statistics where it was found that employees prefer performing a diverse task rather than specializing in a particular task and, as an impact, job rotation aggregates job satisfaction. It is a substantial solution to this labor force has inadequate motivation because it encourages them to accomplish higher performance, achieve continuous growth the job, sustained knowledge and skill, and increasing employeecustomer quality. Scholars have also anticipated that job rotation may assist labor force to obtain multiple capabilities and increase vision, and that it can be a way to decrease job burnout. This study focused on job rotation and motivation and utilized mixed method research design in collection of data, however the current study used a questionnaire alone in its data collection with its major interest being job rotation.
Kampkötter, Harbring and Sliwk (2018) also conducted a research on job rotation at German financial and banking industry. In this study, the researcher mainly focused on the influence of the employee's prior performance and his ability to rotate and to examine the ability of an employee to rotate from one function to another. After evaluating a panel data from the industry, the study found that high and low performers were able to rotate effectively but lateral rotation among low performers was found to be frequent. It was established that employees who had rotated achieved improved performance as compared to their counterparts who had not rotated between different job functions. The study concluded that there was a significant relationship between job rotation of high performers and performance while there was no significant relationship between rotation of low performers and their performance. The context of the study was in banking industry in Germany where panel data was used, while the current study's focused on level four hospitals in the south rift region in Kenya with cross sectional design being used in data collection.

Sanali, Bahron, and Dousin, (2013) performed a research in Sabah, Malaysia on practices related to job rotation, motivation and stress and among diplomatic and administrative officers showed the existence of a positive and significant relations between motivation and practices employed during job rotation. The study concluded that the department of human resources must have the capability of designing and developing a task suiting each employment level. Service scheme in the modern world integrates practices incorporating job rotation include the diplomatic and administrative services. Diplomatic and administrative scheme normally adopt those schemes that are shared in public sector which could be assigned in foreign or domestic offices of any federal departments, ministries and agencies. Such scheme was usually under the Malaysian Public Service Department supervision that is responsible for formulating, making plans and implementing organizational management and human resource policies. This scheme's workforce is mobilized to any government departments or post ministries. The study took place in Malaysian public service with job rotation, motivation and stress being studied which is different from the current study that is looking at job rotation in level four hospitals in the south rift region in Kenya. Tabiu, Pangil and Othman, (2016) conducted a study on the linkage between employee performance and practices related to human resource in the Nigerian public sector. Data was gathered from selected state offices by application of questionnaires. The results of their research were as follows; initially, they found that employee's tenure negatively affected the rate of job rotation: the rotation of young employees was frequent than senior employees. Second, the rate of job rotation was not influenced by educational level. Third, the rate of rotation was influenced positively by individual performance and finally the rate of promotion was moderate positive by rate of rotation. Therefore, the study concluded by indicating that there are various factors which influence the effectiveness of job rotation. This study however relied on data collected by use of questionnaires from selected departments only. The current study differs with the reviewed study in context and scope, whereas the current study was conducted in level four hospitals in the south rift region in Kenya, the reviewed study took place in the Nigerian public sector.

Tarus (2014) in study to assess the effects of job rotation strategy on high performance workplace, in Lake Victoria North 
Water Services Board, Kenya, established that rotation of job as a training technique had a substantial impact on the workplace high performance. The study concluded that job rotation had a positive influence on performance of the organization. The study was carried out by adopting explanatory survey research design, stratified sampling and simple random sampling techniques were also used to identify the respondents of the study. Data analysis and hypothesis testing was carried out using structural equation model. This study however relied purely on secondary data by use of explanatory survey research design whereas the current study adopted a correlational research design using both primary and secondary data. The context was also different, i.e while the current study is focusing on level four hospitals, the reviewed study focused on Lake Victoria water service board.

Tuei and Saina (2015) varied out a study entitled Job Rotation: An Examination of Its Effect on Employee Performance at KCB Branches in The North Rift Region, Kenya. The study found that the management of $\mathrm{KCB}$ required to redesign and restructure their framework for job rotation motivator which is non - financial to improve performance their employees. In carrying out this study, the researcher adopted a case study research design and a census technique where all the six commercial banks from the North Rift Region were considered for the study. The study relied on both primary and secondary data which was analyzed qualitatively and quantitatively using SPSS. After regression and correlation analysis, the findings established that job rotation had a coefficient that was significantly positive with employee performance. However, this study left a methodological research gap to be filled in that it adopted a case study research design while the current study adopted a correlational research design.

\subsection{Employee Performance}

Organizational development and growth are influenced by numerous factors including training and development which plays a considerable role. Training and development play an important role in enhancing employee service delivery and ultimately the overall performance of the organization. Existing empirical literature offers evidence of the influence of training and development techniques on employee performance. Some studies have examined organizational performance as a result of employee performance (Alasadi \& Al Sabbagh, 2015) while some have looked at it broadly as organizational performance (Adongo, 2013). The former is at the level of individual employee while the latter is at organizational level, however, the focus of the present study is on employee performance.

Makhamara, Waiganjo and Kwasira, (2016) suggest that the competencies of workers change through development techniques and effective training. These techniques not only improve the general performance of workers in executing their duties but also promote their skills, knowledge and attitude towards meeting the future demands in the job, thus promoting sustainable performance of the firm.

Training and development techniques and practices such as job rotations have been found to have an influence on employee performance through developing employee skills, competencies, knowledge, ability, and appropriate behaviors. If the training techniques are implemented appropriately, performance of the organization will also improve, (Garner, 2012). However, Hage (2017) argued that training may not be the only technique that can be used to improve employee performance but it has a great influence as compared to other techniques. It is therefore recommended that the organization should constantly adopt new methods and techniques to improve performance of the employees.

Based on the literature reviewed, it was established that majority of the studies have been conducted in corporate, manufacturing and the financial sectors with none reviewed focusing on the health sector. The methodologies used in the studies also differ with most studies adopting descriptive, case study, and explanatory survey research designs with only a few employing correlational research design. This leaves a question as to whether the inconsistencies in the research findings is due to the scope and differences of research designs adopted. Therefore, on this basis the researcher sought to assess the relationship that exists between job rotation and performance of employee in level four hospitals in the Kenya's south rift region using a correlational research design where both primary and secondary data was collected between May and July 2021.

\subsection{Conceptual framework}

The interplay between job rotation and employee performance is presented in the figure below.

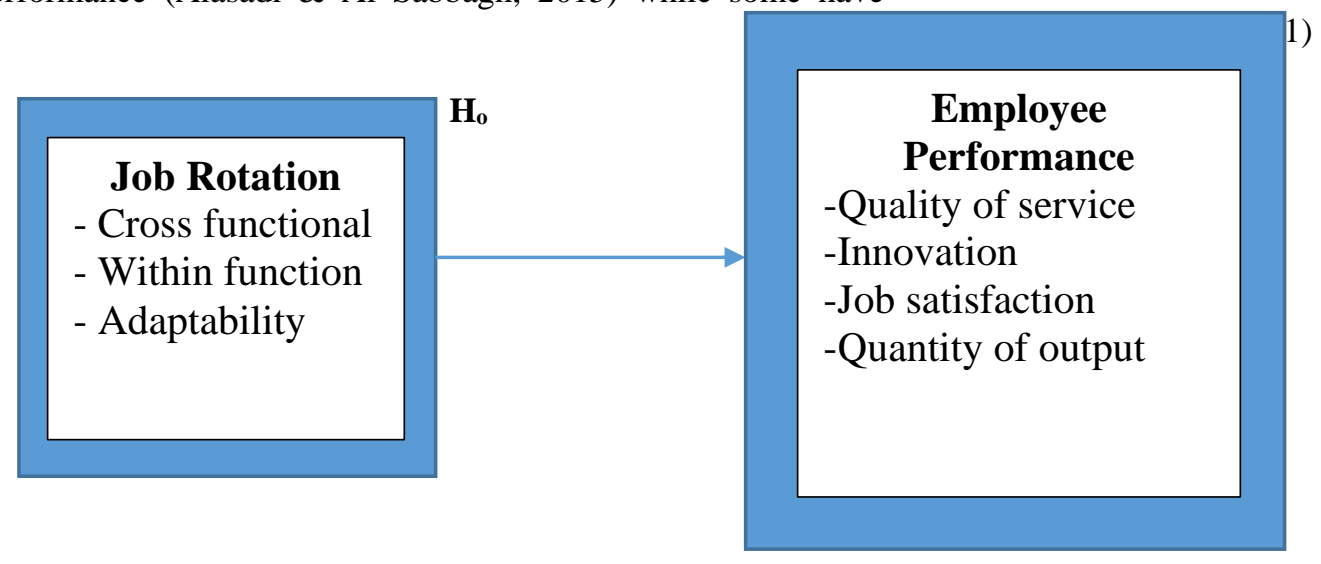

\section{Independent Variable Variable}

\section{Dependent}

Figure 1.1: Conceptual framework 


\section{RESEARCH METHODOLOGY}

This study adopted a correlational and survey study research designs. According to Orodho, (2012) correlation research design is appropriate to the study as it sought to examine the relationship between variables under study. The study was carried out in the south rift region in Kenya which is located in the south east of Nairobi which is the capital city of Kenya. The region is comprised of three counties namely, Kericho, Narok and Bomet. The area was selected for the study because of the large number of level four hospitals where performance of majority of them is below average. The target population of this comprised of health workers from the Level Four hospitals within South Rift Region which has 13 hospitals and 663 employees. A sample size of 249 was selected with Proportionate stratified sampling technique being employed to determine the sub-samples in each county. Simple random Sampling was then applied to select the respondents. Primary data on job rotation and employee performance was obtained using a structured five-point Likert scale questionnaire. Secondary data on measurement of job rotation and employee performance was obtained from literature published as peer reviewed work by researchers, books, periodicals and other related publications. Mean and standard deviation analytical methods were used to summarize data while regression and correlation analysis employed to test the relationship between job rotation and employee performance. Lastly before data was collected the respondents were informed about the procedures to be used in conducting the research and were requested for their consent to before participating in the exercise. Their respondents' opinions and ideas were respected and treated with outmost confidentiality during the entire exercise. Generally, a highest degree of sincerity and openness regarding the aim and nature of the study was observed.

\section{RESULTS AND DISCUSSION}

\subsection{Job Rotation and Employee Performance of Level Four Hospitals}

The objective was to establish the relationship between job rotation and employee performance in level four hospitals within South-Rift region in Kenya

Hypothesis stated: There is no significant relationship between job rotation and employee performance in level four hospitals within South-Rift region in Kenya.

The model was presented as; -

$\mathbf{Y}=\boldsymbol{\beta} \mathbf{0}+\boldsymbol{\beta}_{1} \mathbf{X}_{1}+\boldsymbol{\beta}_{2} \mathbf{X}_{2}+\boldsymbol{\beta}_{3} \mathbf{X}_{3}+\boldsymbol{\varepsilon}$

Where $\mathbf{Y}=$ Performance of Employee

$\boldsymbol{\beta 0}=$ Constant

$\boldsymbol{\beta}_{1}, \boldsymbol{\beta}_{2}, \boldsymbol{\beta}_{3}=$ Beta coefficient

$\mathbf{X} \mathbf{1}=$ Cross function rotation; $\mathbf{X}_{\mathbf{2}}=$ within function rotation and $\mathbf{X}_{\mathbf{3}}$

= Adaptability

$\boldsymbol{\varepsilon}=$ Error Term

Table 1: Model Summary for Regression Analysis for Job Rotation and Performance

\begin{tabular}{llllll}
\hline Variable & $\begin{array}{l}\text { No. } \\
\text { Observations }\end{array}$ & Beta & $\begin{array}{l}\text { Standard } \\
\text { Error }\end{array}$ & t- Statistic & p-value \\
& & & & & \\
& & & & \\
Constant & 227 & 4.978 & 0.164 & 30.339 & $.000^{\mathrm{b}}$ \\
Job Rotation & 227 & 0.406 & 0.039 & 10.410 & \\
$\mathbf{R}=0.506$ & & & & & \\
$\mathbf{R}^{2}=0.256$ & & & & \\
$\mathbf{F}=2.564$ & & & & \\
Durbin Watson $=1.607$ & & & & \\
\hline
\end{tabular}

$* \mathbf{p}<0.05$

Source: Research Data, (2021)

The results in table 1 indicates the regression analysis on the relationship between job rotation and performance of level four hospitals within the South-Rift region in Kenya, the value for Durbin-Watson $(\mathrm{D}=1.607)$ is also within the established range of 1-3 indicating the absence of autocorrelation in the sample.

The correlation on the relationship between job rotation and performance was positive and significant $(\mathrm{R}=0.506, \mathrm{p}<0.05)$. This means that there was a significant relationship between job rotation and performance indicating that whenever Level Four Hospitals in the South-Rift region in Kenya rotated the jobs there was a significant improvement in their performance.

The results of the regression further indicated that job rotation significantly predicted firm performance $(\beta 1=0.406, t=$ $10.410 ; \mathrm{p}<0.05)$, which means a unit increase in job rotation produced a 0.406 variation in performance. The $\mathrm{R}$ squared value indicated that job rotation explained $25.6 \%$ of the variance in performance $\left(\mathrm{R}^{2}=0.256, \mathrm{~F}=2.564 ; \mathrm{p}<0.05\right)$. This demonstrates that the larger proportion of disparity in firm performance $(74.4 \%)$ is explained by other factors not captured in the first model. The hypothesis that there is a significant relationship between job rotation and performance of Level Four Hospital in the South-Rift region in Kenya is therefore supported.

The findings are supported by Akbari and Maniei (2017) who also established similar results in their study that revealed that when job rotation was adopted, employees were able to obtain new skills and experiences which increased their performance. Azzopardi, (2019) also concurred with the study findings that employees prefer performing a diverse task rather than specializing in a particular task and therefore it was established that job rotation improved job satisfaction. Similarly, Azzopardi, (2019), Kuzey (2012), Kampkötter, Harbring and Sliwk (2018) and Tabiu, Pangil and Othman, (2016) also concurred with the study findings that employees prefer performing diverse task 
rather than specializing in a particular task and therefore it was established that job rotation improved job satisfaction. However, Tarus (2014) and Sanali, Bahron, and Dousin, (2013) established that job rotation can only be fruitful if implemented according to the goals of the organization and when the management has enough capacity to design and develop tasks that suit each employment level

\section{CONCLUSION}

The findings of the study established that health workers at the hospitals preferred job rotation which is within the function. It was also established that job rotation was dependent on employees' adaptability to a particular job at the hospital. Majority of the respondents concurred that job rotation between different departments at the hospital breaks monotony and thus contributing to enhanced employee motivation. This positive attributes will in turn improve performance of the level four hospitals. This implies that inefficient implementation of job rotation technique adversely affects performance. The study further concluded that quality service delivery at the hospitals was attributed to the effectiveness of job rotation practices. Job rotation also ensured that employees acquire different skills hence improving their performance.

\section{RECOMMENDATIONS}

From the findings, the study recommended that level four hospitals in the south rift region should adopt and implement human resource policies such as job rotations that may help them improve the efficiency of the training techniques. To make job rotation more effective, health workers should rotate within the job function. This is because each employee possesses unique technical knowledge and skill. Therefore, they can be rotated in different sections but performing similar tasks.

\section{REFERENCES}

[1] Adenyo, A. (2016). Effect of training and development on organizational performance: a case of compassion international Ghana assisted projects in the Volta Region (Doctoral dissertation, University of Cape Coast).

[2] Adongo, A. J. (2013). Examining the effects of job training on employee performance in mobile telephone industry: A case of Telkom Orange Nakuru, Kenya. (Unpublished master's thesis). Kenyatta University, Nairobi, Kenya

[3] Akbari, A., \& Maniei, R. (2017). The Effect of Job Rotation on employee performance. Research Journal of Management Reviews, 3(1), 21-26.

[4] Alasadi, R., \& Al Sabbagh, H. (2015). The role of training in small business performance. International Journal of Information, Business and Management, 7(1), 293.

[5] Azzopardi, A. (2019). Internal job rotation within Maltese audit firms (Master's thesis, University of Malta).

[6] Bandura, A., \& Walters, R. H. (1977). Social learning theory (Vol. 1). Englewood Cliffs, NJ: Prentice-hall.

[7] Becker, G. S. (1993). Nobel lecture: The economic way of looking at behavior. Journal of political economy, 101(3), 385-409.

[8] Creswell, J. W., \& Creswell, J. D. (2017). Research design: Qualitative, quantitative, and mixed methods approaches. Sage publications.

[9] Elnaga, A., \& Imran, A. (2013). The effect of training on employee performance. European journal of Business and Management, 5(4), 137-147.

[10] Esteban-Lloret, N. N., Aragón-Sánchez, A., \& Carrasco-Hernández, A. (2018). Determinants of employee training: impact on organizational legitimacy and organizational performance. The International Journal of Human Resource Management, 29(6), 1208-1229.

[11] Garner, E. (2012). Training skills: How to improve the skills and performance of your employees. Ventus: Eric Garner \& Ventus Publishing APS. Available at: http://www. bookboon. com.

[12] Hage, J. (2017). Human Capital. The Wiley-Blackwell Encyclopedia of Social Theory, 1-2.

[13] Halawi, A., \& Haydar, N. (2018). Effects of training on employee performance: A case study of Bonjus and Khatib \& Alami Companies. International Humanities Studies, 5(2), 24-45.

[14] Kampkötter, P., Harbring, C., \& Sliwka, D. (2018). Job rotation and employee performance-evidence from a longitudinal study in the financial services industry. The International Journal of Human Resource Management, 29(10), 1709-1735.

[15] Kuzey, C. (2012). Impact of Health Care Employees' Job Satisfaction On Organizational Performance Support Vector Machine Approach. European Journal of Economic \& Political Studies, 5(1).

[16] Makhamara, F. H., Waiganjo, E. W., \& Kwasira, J. (2016). Influence of strategic recruitment and selection on employee performance in the health sector in Kenya. Strategic Journal of Business \& Change Management, 3(21), 347.

[17] Mineka, S., \& Zinbarg, R. (2006). A contemporary learning theory perspective on the etiology of anxiety disorders: it's not what you thought it was. American psychologist, 61(1), 10.

[18] Morley, M. J., Slavic, A., Poór, J., \& Berber, N. (2016). Training practices and organisational performance: A comparative analysis of domestic and international market oriented Organisations in Central \& Eastern Europe. Journal of East European Management Studies, 406-432.

[19] Mutua, J. M. (2017). Assessing the influence of human resource management practices on employee performance in the health sector in Machakos County, Kenya; (Doctoral dissertation).

[20] Nemeth, J. (2017). Human capital theory in the framework of organization theory. Strategic Management, 22(3), 29-35.

[21] Newman, S., Baum, A., \& Wienman, J. (1995). Social Learning Theory: Self Efficacy in Changing Societies.

[22] Njoroge, S. W., \& Kwasira, J. (2015). Influence of compensation and reward on performance of employees at Nakuru County Government. Journal of Business and Management, 17(11), 87-93.

[23] Nonaka, I., \& Toyama, R. (2015). The knowledge-creating theory revisited: knowledge creation as a synthesizing process. In The essentials of knowledge management (pp. 95-110). Palgrave Macmillan, London.

[24] Orodho, A. J. (2009). Techniques of Data Analysis Using Statistical Package for Social Sciences (SPSS) Computer Package. Maseno, Kenya: Kanezja Publishers.

[25] Sanali, S., Bahron, A., \& Dousin, O. (2013). Job rotation practices, stress and motivation: An empirical study among administrative and diplomatic officers (ADO) in Sabah, Malaysia. International Journal of Research in Management \& Technology, 3(6), 160-166.

[26] Schwab, R. (2018). Indigenous participation in higher education: Culture, choice and human capital theory. Canberra, ACT: Centre for Aboriginal Economic Policy Research (CAEPR), The Australian National University.

[27] Tabiu, A., Pangil, F., \& Othman, S. Z. (2016). Examining the link between HRM Practices and Employees' performance in Nigerian public sector. Management Science Letters, 6, 395-408.

[28] Tarus, B. K. (2014). Effects of Job Rotation Strategy on High Performance Workplace, in Lake Victoria North Water Services Board, Kenya. International Journal of Business and Management, 9(11), 139.

[29] Tuei, A. C., \& Saina, P. C. (2015). Job rotation: An examination of its effect on employee performance at KCB branches in the north rift region, Kenya. International Journal of Advanced Research in Management and Social Sciences, 4(5), 84-93.

[30] Winter, S. G. (1988). On Coarse, competence, and the corporation. JL Econ. \& Org., 4, 163.

\section{AUTHORS}

First Author - Sharon Cherotich, MBA, School of Business and Economics, University of Kabianga, Kenya 
Second Author - Dr. Williter Rop, Lecturer, School of Business and Economics, University of Kabianga - P.O Box 2030-20200 Kericho, Kenya

Third Author - Dr. Alfred Bett, Lecturer, School of Business

and Economics, University of Kabianga - P.O Box 2030-20200

Kericho, Kenya 